\title{
曲げを受ける曲線プレートガーダーの \\ ウェブプレートの弾性挙動について \\ ELASTIC BEHAVIOR OF WEB PLATES OF CURVED PLATE GIRDERS IN BENDING
}

\author{
倉西茂*・樋 渡滋** \\ By Shigeru KURANISHI and Shigeru HIWATASHI
}

\section{1. まえがき}

プレートガーターおよびボックスガーターなどの曲げ を受ける鋼構造部材の断面は一般にフランジとウェブプ レートからなっている. フランジは主として曲げモーメ ントに抵抗し，ウェブプレートはせん断力を受け持つと ともにフランジ閒の距離を保つ役割をもっている.そこ で経済的に曲げを受ける断面を構成しようとすると，曲 げに対して貢献の少ないウェブプレートの板厚をできる 限り薄くし，かつウェブ高を高くすることが望まれる. しかし, ウェブプレートを薄くすると, 当然その座屈が 問題になるし, 座屈後の挙動に注意を払う必要が生じて くる. Basler ${ }^{1}$ らは薄いウェブプレートを用いた場合， その避けられない元たわみおよびその有限変形挙動を考 え,フランジとともに有效に㗢くウェブ部分を実験結果 より考察している.

近年, 都市高速道路の発達とともに, 曲線プレートガ ーダーおよび曲線ボックスガーダーが多く用いられるよ らになってきているが, これら曲線橋のウェブプレート は，その曲率に合わせて製作されるのが普通である。す なわち, ウェブプレートは面外に曲率を有する円筒状と なっており，その面内にはりとしての曲げモーメントが 作用する状態となっている.このため荷重の初期段階よ り, 圧縮部は外側に, 引張部は内側に変形を引き起こす 作用を受け，曲げモーメントの増大とともにウェブプレ 一トに大きな変形が生じる可能性がある.

そこで本論文は，水平補剛材をもたない曲線プレート ガーダーの上下フランジと垂直補剛材で囲まれた 1 パネ ル分のみを取り出し，これに曲げモーメントのみが加わ ったときのウェブの有限変形挙動を数值解析により明ら かにしようとするものである。

* 正会員 工博 東北大学教授 工学部土木工学科

** 正会員 工修 東北学院大学助教授 工学部土木工学科
曲線プレートガーダーのウェブプレートは，元たわみ を考えなければ，フランジと補剛材で囲まれた部分は円 筒パネルとみなすことができる.この円筒パネルとは形 状はシェルの一種であるが，外力が面内方向（円周方 向）に作用する点で本来のシェル構造の役割と異なる. 一般のシェルに関する解析については，いままでに多く の研究がすでになされているが，円筒パネルが，その円 周方向に外力の作用を受ける場合の解析例は数少なく, わずかに，三上・森沢・米沢の一連の研究 2 をを知るのみ である．三上らは曲りばりの円筒状フランジを取り上 ゲ，面内方向に一様圧縮または引張りを受ける場合の非 線形挙動を差分法によって解析しているが，有限変形挙 動洘慮されていない. なお, 大塚・吉村・片桐3) は有 限带板法により曲線 I 桁の弾塑性座屈強度解析を行い, 曲線 I 形ばりの局部座屈と全体座屈を論じている.

曲げの増大とともに円筒パネルとして取り出したウェ ブプレートは, 面外有限変形の影響を受け, ベルヌーイ ・オイラーの断面平面保持の仮定が成り立たなくなり， いわゆる断面の反りは複雑に変化するようになる.そこ で，本論文では，全体構造との側縁での適合性を考え， 側面縁端部は直線を保つような強制変位により曲げ荷重 を与えている. 解析は浅いシェル理論に基づき, 円筒状 要素を用いた有限要素法により, 幾何学的非線形のみを 考慮し, 荷重増分法を用いてその有限変形の影響を求め ている.その結果より，ウェブプレートの曲げに対する 作用，フランジとウェブプレートとの接合部に生じる応 カ，フランジの垂直方向変位に対する影響等が論じられ ている

\section{2. 解 析 法}

(1) 一 般

解析はプレートガーダーのウェブを円筒パネルとみな 
して有限要素法で行った. 曲面構造を有限要素法で解析 する場合に，多数の平面要素の集合として扱らいわゆる 平面近似の方法があり，その要素の数を増すことによっ てある程度の計算精度の向上が期待できる．しかしなが ら, シェルのような三次元的変形を伴う薄肉構造は複雑 な幾何学的性状をもつため, 連続体を離散化するための 誤差が, 要素数を増加させることによる計算精度の向上 を打ち消す可能性を有する，曲面要素を用いると，計算 精度を低下させる幾何学的不適合（隣接要素間で共通の 変位角あるいは指定された変位角をもたないこと）は避 けることが可能である. したがって，円筒パネルを解析 する場合, 四角形円筒要素を用いることは変位関数の定 め方によるが計算精度の低下の一因を減少させるという 観点から有效である.

本論文の解析は四角形円筒要素を用いて行われた．四 角形円筒要素を用いる場合の変位関数の定め方について は，いままでいくつかの提案がなされている ${ }^{4) \sim 10) . ~}$

本論文では曲線ウェブプレートの幾何学的非線形变形 問題を扱っているが，荷重増分法を使用することを前提 として, 剛体变位の影響の評価に多少難点はあるが比較 的単純な変位関数をもつ Brebbia and Connor ${ }^{4)}$ の式を 採用した。

$$
\begin{aligned}
& u=\alpha_{1}+\alpha_{2} x+\alpha_{3} y+\alpha_{4} x y \cdots \cdots \cdots \cdots \cdots \cdots(1 \cdot \mathrm{a}) \\
& v=\alpha_{5}+\alpha_{6} x+\alpha_{7} y+\alpha_{8} x y \cdots \cdots \cdots \cdots \cdots \cdots(1 \cdot \mathrm{b}) \\
& w=\alpha_{9}+\alpha_{10} x+\alpha_{11} y+\alpha_{12} x^{2}+\alpha_{13} x y+\alpha_{14} y^{2} \\
& +\alpha_{15} x^{3}+\alpha_{16} x^{2} y+\alpha_{17} x y^{2}+\alpha_{18} y^{3} \\
& +\alpha_{19} x^{3} y+\alpha_{20} x y^{3}
\end{aligned}
$$

ここで, $u, v, w$ は図一1 のように円筒パネルの母線方 向に $X$ 軸, 円筒方向に $Y$ 軸, 面外方向に $Z$ 軸をとっ たときの $x, y, z$ 方向の変位であり, $x, y$ は $X, Y$ 方 向の座標值， $\alpha_{1} \sim \alpha_{20}$ は未定係数である.

解析は, 一般的な有限要素解析手順に従っているので 説明を省略するが，解析に際して仮定された事項を以下 に記す。

（a）パネルの形状は浅い円筒形である.

（b） 円筒パネルの板厚は，パネルの代表寸法よりは るかに小さい

（c）変形前に円筒パネルの中央面に垂直であったあ らゆる直線は, 変形後も直線に保たれかつ変形後の中央 面に垂直である.

（d） 円筒パネルの厚さ方向のせん断変形は考慮しな w.

（e）材料の鋼材は等方性弾性材料とみなし，塑性 の影響法考慮しない.ヤング率は $E=2.1 \times 10^{6} \mathrm{kgf} / \mathrm{cm}^{2}$ (205.8 MPa) とする.

（f） 円筒パネルには残留応力等の初期応力および初 期変形はないものとする。

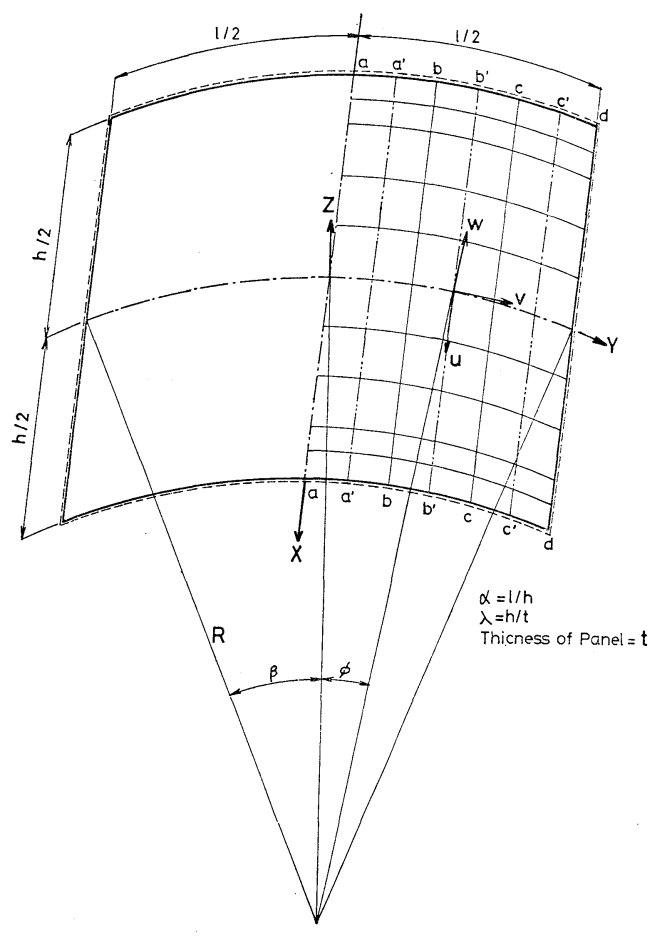

図一1 有限要素解析

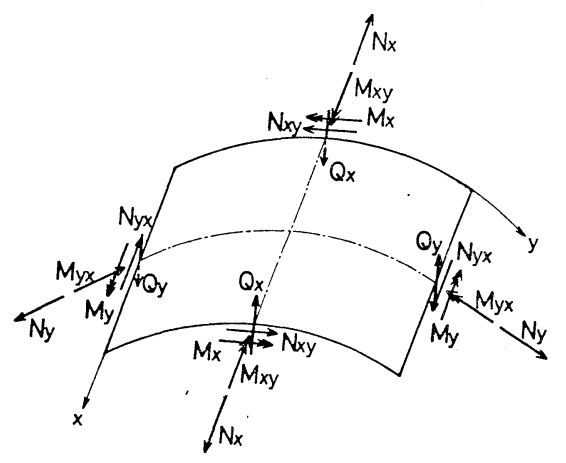

図一2 合応力と合モーメント

（g）縁端部において中央面の接線方向に作用する外 力の方向は一定とし, 変形後も変わらない.

（h） 中央面に平行な変位 $u, v$ は微少であり，ひず みと変形の関係では $\partial w / \partial x, \partial w / \partial y$ の 2 次の項で表わ される非線形項だけを考慮する.

非線形つり合い方程式の解法は，荷重増分法と Newton-Raphson 法を組み合わせた方法を採用し，収束のた めの繰返しは不平衡力による変位変動が $3 \%$ 以下になる 段階まで行った。

各要素に生ずる合応力と合モーメントを 図一2 に示 す.

\section{（2）境界条件およひ強制変位}

曲げを受ける曲面ウェブを解析する場合，上下フラン 
ジと垂值補剛材に囲をれた部分を部分構造として取り上 げることができる．この部分構造は円筒パネルとみなす ことができるが，パネルの支持条件や載荷方法によって 解析結果に差異が生ずる.したがって,適当な境界条件を 選定することが重要であり，その選定のため に次の 4 種の境界条件を設定して比較を行っ た. いずれの場合も載荷辺は可動ヒンジで支 持され辺に沿う方向の変位 $(u)$ と $Y$ 軸回り の回転 $\left(\theta_{X}=\partial w / \partial x\right)$ が拘束されていること および非載荷辺で $X$ 軸回りの回転 $\left(\theta_{Y}=\right.$ $\partial w / \partial y)$ が拘束されていることは共通である (図-3).

a）非載荷辺をヒンジで支持 し，載荷辺に曲げ応力分布に相当 する分布荷重 $\left(\sigma_{0}\right)$ を作用させた もの (Case-A).

b） a）の非載荷辺を可動ヒン ジで支持したもの (Case-B).

c） b）の分布荷重の代わりに 曲げ変形に相当する強制変位 $\left(\delta_{0}\right)$ を与えたもの (Case-C).

d） c）の曲げ応力分布の状態 を改善するために，適当な面内軸 方向強制変位 ( $Y$ 軸方向) $\left(\delta_{H}\right)$ を 追加したもの (Case-D).

Case-A Case-D の比較を $h=$ $120 \mathrm{~cm}, \alpha=1.0, t=0.5 \mathrm{~cm}, R=$ $30 \mathrm{~m}$ の場合について図一 4 6 に示す. 図一4 はパネル中央部 (a-a 断面) の面外変位 (w) と面内 垂直変位 $(u)$ を比較したものであ る. Case-A では面外変位が小さ く, その分布形も Case-B, C, D と大きく異なる. 垂直方向変位を 拘束しない Case-B, C, D では上 下フランジの間隔が縮まり見かけ 上の垂直圧縮ひずみが生じてい る. 図一5 は $\mathrm{a}^{\prime}-\mathrm{a}^{\prime}$ 断面の面内曲 げ応力度 $\sigma_{y}$ の分布を示したもの である. Case-A の分布はほぼ直 線に近く線形解析の結果に近い. 他の Case では圧縮縁での応力 の増加が著しい。図一6 は載荷辺 (d-d 断面) での面内水平変位 (v) の分布を示している. Case-A, B の場合, 載荷辺の直線性が失われ ており, 部分構造に部ける全体構
造との適合条件を満足しない.この点を考慮して,載荷辺 で分布荷重の代わりに辺の直線性を保持したまま曲げ変 形に相当する強制変位を与えたものが Case-C である. この場合，面内曲げ応力分布において圧縮応力の総量が

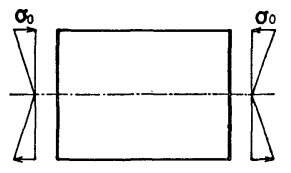

（a）曲け荷重 Case-A, B

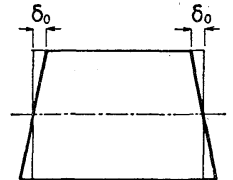

(b) 強制変位 Case-C

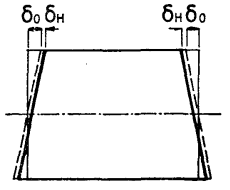

(c) 俭制变位之 铜整变位
Case-D

\section{図一3 荷重と強制変位}

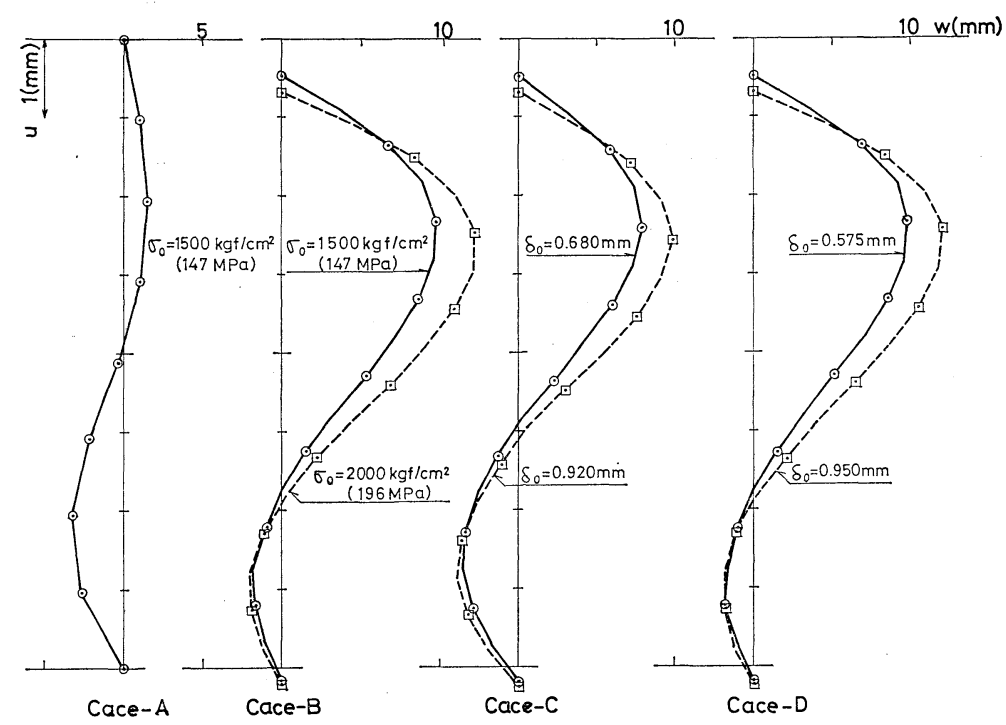

図一4 面外変位と面内垂直変位 $(h=1200 \mathrm{~mm}, \alpha=1.0, t=5 \mathrm{~mm}, R=30 \mathrm{~m})$

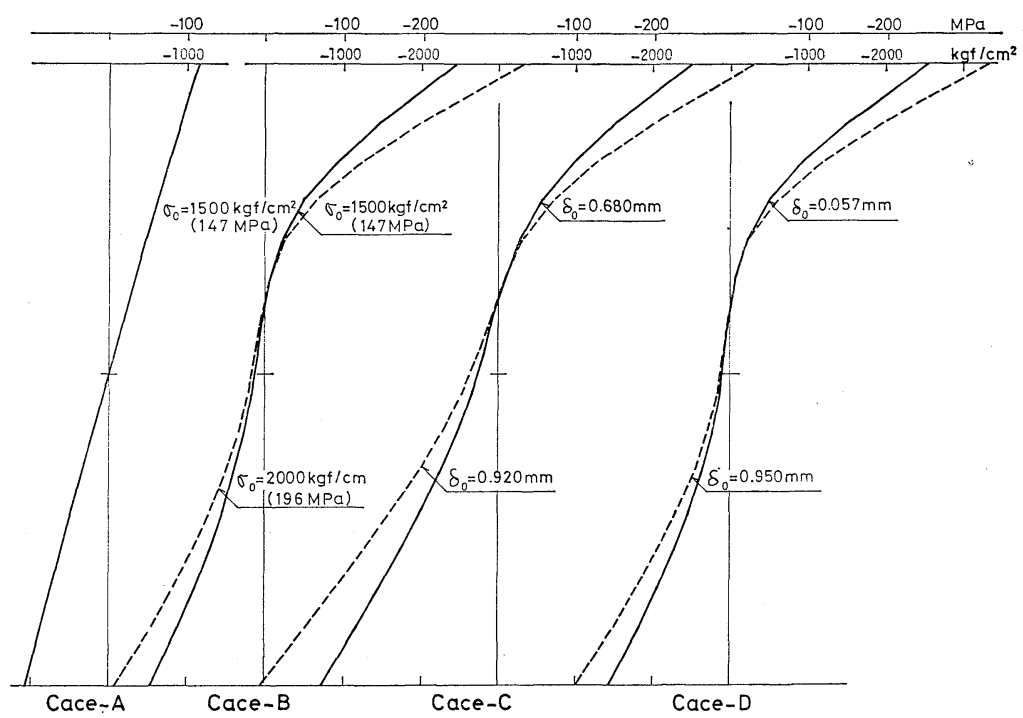

図一5 面内曲げ応力分布 $(h=1200 \mathrm{~mm}, \alpha=1.0, t=5 \mathrm{~mm}, R=30 \mathrm{~m})$ 


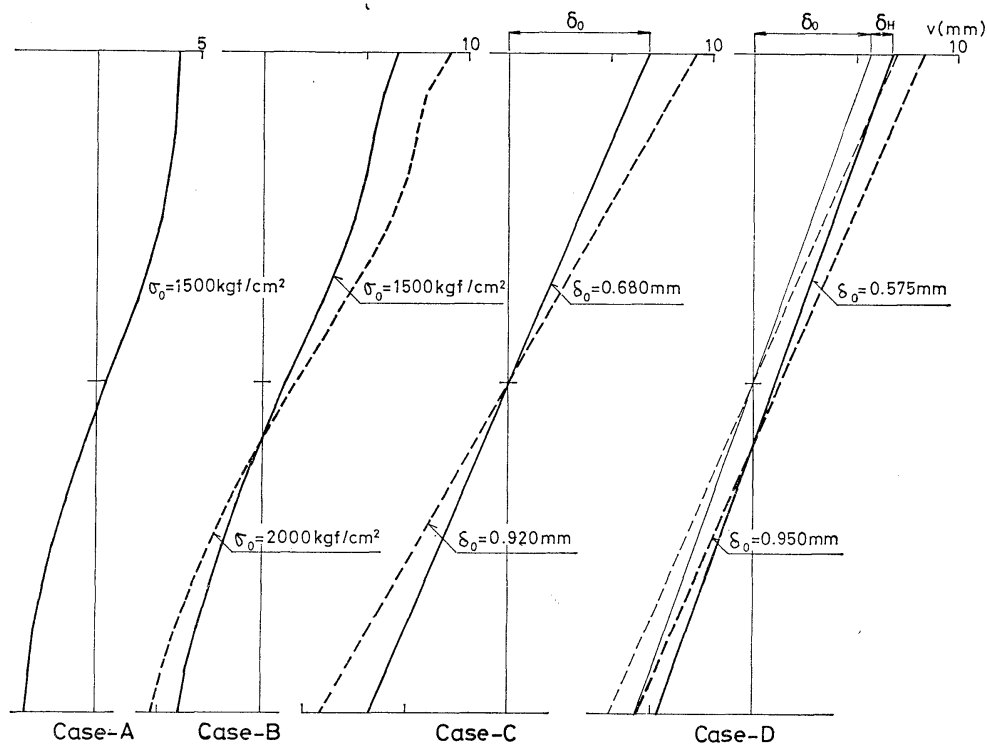

図一6 載荷辺（d-d 断面）の水平変位

本論文では特にことわらない限 り Case-D の条件によって計算 されたものを用いている.この場 合, 曲げ応力分布を修正するため の水平方向圧縮変位量が，上下縁 における曲強制変位量の $8 \%$ 以 内になるまで繰り返して計算され た.

\section{（3）分割数および精度}

有限要素法により解析を行う場 合，計算精度を向上させるために より小さな要素に分割することが 望ましい，一方，要素数は計算機 の記憶容量と計算時間の制約を受 け，ある限度内に押えられる。し たがって，解析の目的に応じて適 当な分割法および分割数を選定し

引張応力のそれより小さくなり（図一5), 純曲げモーメ ントが作用している状態にならない，純曲げを作用させ るためには引張応力を打ち消乙圧縮応力を増加させる必 要があり，このために断面の平面保持を保ちながら適当 な水平方向圧縮変位 $\left(\delta_{H}\right)$ を加えたも のが Case-D である. 図一6 の CaseD において細線 $\delta_{H}$ を与えない Case-C と同様の状態を示している.

実際構造においては，大きなフラン ジをもつボックス断面では Case-C の 状態に近く，付加される水平方向圧縮 応力は上下フランジに負荷され，圧縮 縁では応力の増大を，引張縁では応力 の低下をきたす。したがって，ボック ス断面などのフランジ応力の議論をす るときは Case-Cにより計算し，この 面内水平方向圧縮力の值の評価が必要 となるものと思われる. 小さなフラン ジをもった断面では Case-D の状態に 近いものと思われ，フランジによる圧 縮応力の軽減を受けない Case-D の場合が 曲げ作用を受けるウェブにとって厳しい状 態になっているものと考えられる．表一1

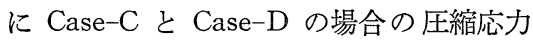
の比較を示す. 表中で $\varepsilon_{0}=2 \delta_{0} / l$ である. 全圧縮応力ならびに圧縮縁応力度ともに Case-C は Case-D より 8〜30\%小さく,一 般にその差は応力レベルが高くなるにつれ て著しくなる.
なければならない，今回はウェブの面内曲げ応力分布性 状の解析をおもな目的として，図一7 のような分割を行 い，計算結果の比較を行った．パネルの境界条件は Case-B として非線形方程式の収束判定の精度を 0.5\% 表一1 Case-C と Case-D における圧縮応力の比較

\begin{tabular}{|c|c|c|c|c|c|c|c|c|}
\hline \multirow{2}{*}{$\varepsilon_{0}$} & & & \multicolumn{3}{|c|}{$\alpha=0.667, t=8 \mathrm{~mm}, R=30 \mathrm{~m}$} & \multicolumn{3}{|c|}{$\alpha=1.0, t=5 \mathrm{~mm}, R=60 \mathrm{~m}$} \\
\hline & & & Case-C & Case-D & $\mathrm{C} / \mathrm{D}$ & Case-C & Case-D & $\mathrm{C} / \mathrm{D}$ \\
\hline \multirow{2}{*}{0.001} & $\Sigma \sigma$ & $\underset{(\mathrm{kN})}{\mathrm{kgf}}$ & $\begin{array}{l}38669 \\
(379.0)\end{array}$ & $\begin{array}{l}41888 \\
(410.5)\end{array}$ & 0.923 & $\begin{array}{l}21389 \\
(209.6)\end{array}$ & $\begin{array}{l}24004 \\
(235.2)\end{array}$ & 0.891 \\
\hline & $\sigma_{c \cdot \max }$ & $\begin{array}{c}\mathrm{kgf} / \mathrm{cm}^{2} \\
(\mathrm{MPa})\end{array}$ & $\begin{array}{c}2221 \\
(217.7)\end{array}$ & $\begin{array}{c}2503 \\
(245.3)\end{array}$ & 0.887 & $\begin{array}{c}2192 \\
(214.8)\end{array}$ & $\begin{array}{c}2603 \\
(255.1)\end{array}$ & 0.842 \\
\hline \multirow{2}{*}{0.002} & $\Sigma^{\sigma}$ & $\underset{(\mathrm{kN})}{\mathrm{kgf}}$ & $\begin{array}{l}64703 \\
(634.1)\end{array}$ & $\begin{array}{c}72663 \\
(712.1)\end{array}$ & 0.890 & $\begin{array}{l}35032 \\
(343.3)\end{array}$ & $\begin{array}{l}45120 \\
(442.2) \\
\end{array}$ & 0.776 \\
\hline & $\sigma_{c \cdot \max }$ & $\begin{array}{c}\mathrm{kgf} / \mathrm{cm}^{2} \\
(\mathrm{MPa})\end{array}$ & $\begin{array}{c}4676 \\
(458.2)\end{array}$ & $\begin{array}{c}5613 \\
(550.1)\end{array}$ & 0.833 & $\begin{array}{c}4219 \\
(413.5)\end{array}$ & $\begin{array}{r}5154 \\
(505.1)\end{array}$ & 0.819 \\
\hline \multirow{2}{*}{0.003} & $\sum \sigma$ & $\underset{(\mathrm{kN})}{\mathrm{kgf}}$ & $\begin{array}{l}87947 \\
(861.9)\end{array}$ & $\begin{array}{c}101777 \\
(997.4)\end{array}$ & 0.864 & $\begin{array}{l}42017 \\
(411.8)\end{array}$ & $\begin{array}{l}65851 \\
(645.3)\end{array}$ & 0.638 \\
\hline & $\sigma_{c \cdot \max }$ & $\begin{array}{c}\mathrm{kgf} / \mathrm{cm}^{2} \\
(\mathrm{MPa})\end{array}$ & $\begin{array}{c}7081 \\
(693.9)\end{array}$ & $\begin{array}{c}8673 \\
(850.0)\end{array}$ & 0.816 & $\begin{array}{c}6746 \\
(661.1)\end{array}$ & $\begin{array}{c}7729 \\
(757.4)\end{array}$ & 0.873 \\
\hline \multirow{2}{*}{0.004} & $\sum \sigma$ & $\underset{(\mathrm{kN})}{\mathrm{kgf}}$ & $\begin{array}{c}110146 \\
(1079.4)\end{array}$ & $\begin{array}{c}130121 \\
(1275.2)\end{array}$ & 0.846 & & & \\
\hline & $\sigma_{c \cdot \max }$ & $\begin{array}{c}\mathrm{kgf} / \mathrm{cm}^{2} \\
(\mathrm{MPa})\end{array}$ & $\begin{array}{c}9380 \\
(919.2)\end{array}$ & $\begin{array}{c}11597 \\
(1136.5)\end{array}$ & 0.809 & & & \\
\hline
\end{tabular}

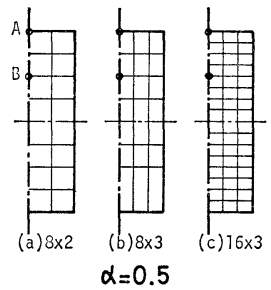

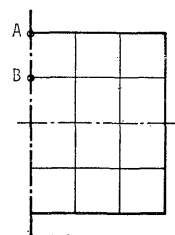

(a) $4 \times 3$

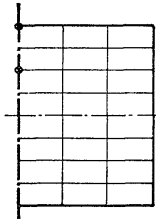

(b) $8 \times 3$

$\alpha=1.5$

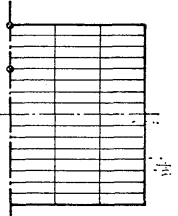

(c) $16 \times 3$ 
表一2 有限要素分割による精度の比較, その 1

\begin{tabular}{|c|c|c|c|c|c|c|c|}
\hline & (a) & (b) & (c) & \multirow{2}{*}{ (a) $/(\mathrm{c})$} & \multirow{2}{*}{ (b) $/(c)$} \\
\hline & & & $16(8 \times 2)$ & $24(8 \times 3)$ & $48(16 \times 3)$ & & \\
\hline \multirow{4}{*}{$\begin{array}{c}\sigma_{0}=700 \mathrm{kgf} / \mathrm{cm}^{2} \\
(68.6 \mathrm{MPa})\end{array}$} & \multirow[b]{2}{*}{ A } & $u \mathrm{~mm}$ & -0.00307 & -0.02614 & -0.02568 & 0.120 & 0.990 \\
\hline & & $\begin{array}{c}F_{Z} \mathrm{kgf} \\
(\mathrm{N})\end{array}$ & $\begin{array}{l}-24.335 \\
(-238.4)\end{array}$ & $\begin{array}{l}-24.921 \\
(-244.2)\end{array}$ & $\begin{array}{l}-24.678 \\
(-241.8)\end{array}$ & 0.986 & 1.010 \\
\hline & \multirow{2}{*}{ B } & $u \mathrm{~mm}$ & -0.01601 & -0.02752 & -0.02748 & 0.583 & 1.003 \\
\hline & & $w \mathrm{~mm}$ & 2.916 & 3.769 & 3.766 & 0.774 & 1.001 \\
\hline
\end{tabular}

表一3 有限要素分割による精度の比較, その 2

\begin{tabular}{|c|c|c|c|c|c|c|c|}
\hline & (a) & (b) & (c) & \multirow{3}{*}{$\frac{(\mathrm{a}) /(\mathrm{c})}{0.878}$} & \multirow{3}{*}{$\frac{(b) /(c)}{0.961}$} \\
\hline & & & $12(4 \times 3)$ & $24(8 \times 3)$ & $48(16 \times 3)$ & & \\
\hline \multirow{4}{*}{$\begin{array}{c}\sigma_{0}=900 \mathrm{kgf} / \mathrm{cm}^{2} \\
(88.2 \mathrm{MPa})\end{array}$} & \multirow[b]{2}{*}{ A } & $u \mathrm{~mm}$ & -0.3651 & -0.3994 & -0.4158 & & \\
\hline & & $\begin{array}{c}F_{Z \mathrm{kgf}} \\
(\mathrm{N})\end{array}$ & $\begin{array}{c}-46.506 \\
(-455.8)\end{array}$ & $\begin{array}{l}-46.342 \\
(-454.2)\end{array}$ & $\begin{array}{l}-46.653 \\
(-457.2)\end{array}$ & 0.997 & 0.993 \\
\hline & \multirow{2}{*}{ B } & $u \mathrm{~mm}$ & -0.3611 & -0.3807 & -0.3890 & 0.928 & 0.979 \\
\hline & & $w \mathrm{~mm}$ & 4.161 & 4.926 & 5.302 & 0.785 & 0.929 \\
\hline \multirow{4}{*}{$\begin{array}{c}\sigma_{0}=2600 \mathrm{kgf} / \mathrm{cm}^{2} \\
(254.8 \mathrm{MPa})\end{array}$} & \multirow[b]{2}{*}{ A } & $u \mathrm{~mm}$ & -1.0892 & - & -1.5442 & 0.705 & - \\
\hline & & $F_{(\mathrm{kN})} \mathrm{kgf}$ & $\begin{array}{c}-176.52 \\
(-1.730)\end{array}$ & - & $\begin{array}{l}-180.36 \\
(-1.768)\end{array}$ & 0.987 & - \\
\hline & \multirow{2}{*}{ B } & $u \mathrm{~mm}$ & -1.0196 & - & -1.2065 & 0.845 & - \\
\hline & & $w \mathrm{~mm}$ & 9.603 & - & 14.907 & 0.644 & - \\
\hline
\end{tabular}

$h=1200 \mathrm{~mm}, R=30 \mathrm{~m}, t=5 \mathrm{~mm}, \alpha=1.5$

\section{3. 解析結果およびその考察}

\section{（1）面内曲げ応力度分布および有 効断面}

プレートガーダーの圧縮フランジの 曲げ座屈時に考慮されるウェブの有効 断面注, 鋼材の塑性化に伴う応力の再 配分などの降伏後の塑性挙動が幾何学 的非線形性と関係して決定される面内 曲げ応力の分布性状に左右されるもの であり,さらにフランジのウェブに対 する拘束度についてもその影響が考 慮されなければならない。しかしなが ら，本論文の上うに現象を単純化した 弾性解析に掠いても有效幅の減少が明 らかに認められるので考察する.この 場合はフランジのねじり拘束を無視し た場合に相当する.

図一8 は $\lambda=240, R=30 \mathrm{~m}$ の場合 の $\mathrm{a}^{\prime}-\mathrm{a}^{\prime}$ 断面の曲代応力度の分布を縦
とした．表一2，3 は節点 A および B での面内垂直変位 $(u)$, 面外方向反力 $\left(F_{Z}\right)$ および面外変位 $(w)$ の精度 の比較を示している. 一般的に, 変位成分についてはば らつきがみられるが，反力については $3 \%$ 以内の変動に 納まっている. 水平方向の分割数が少ない場合, 垂直変 位の值は大きく異なる（表一2（a)）。表一2，3 におい て(b) と（c）との差は変位で 7\%，反力で $1 \%$ 以内で あり, $16 \times 3$ 分割で一応の目的は

達せられると思われる。

\section{(4) パラメーター}

解析は対称性を考慮してパネル の半分について行われている. 計 算対象の部分を 16 ( $X$ 方向 $) \times 3$ ( $Y$ 方向) の 48 要素に分割した ものが基本的なモデルである.

パラメーターは縦横比 $\alpha$, 幅厚 比 $\lambda$ および曲率半径 $R$ とし，そ れぞれ次の範囲で変化させた。

$$
\begin{aligned}
\alpha: & 0.5,0.667,1.0,1.2, \\
& 1.5 \\
\lambda: & 240,150,120,100 \\
R: & 30 \mathrm{~m}, 60 \mathrm{~m}, 120 \mathrm{~m}
\end{aligned}
$$
横比ごとに示したものである. 縦軸に断面の高さを, 横 軸に応力度をとり，曲げ荷重に相当する強制変位を与え た場合の $y$ 軸方向縁ひずみ $\varepsilon_{0}=2 \delta_{0} / l$ をパラメーターと して表示した. 図中細線はそれぞれ線形解析による分布 を示す.

本論文のように載荷辺を単純支持と仮定した場合， $\alpha$ が小さいほど，また $\varepsilon_{0}$ が大きいほど，圧縮縁応力度

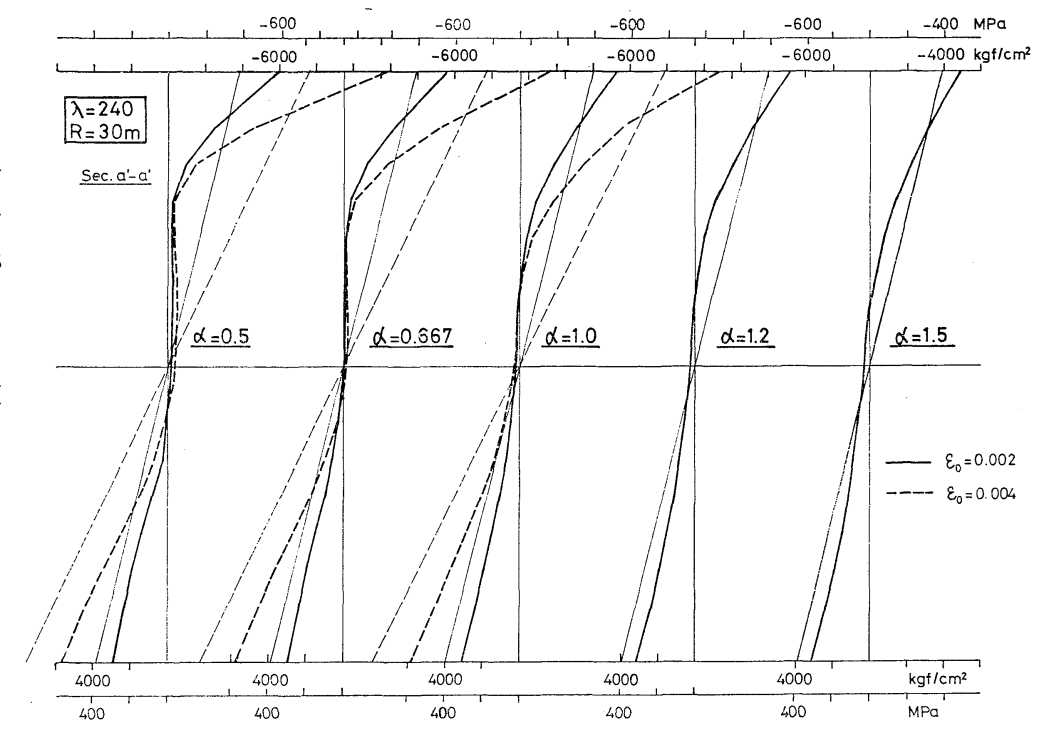

図一8 面内曲げ応力分布 ( $\mathbf{a}^{\prime}-\mathbf{a}^{\prime}$ 断面) $(\lambda=240, R=30 \mathrm{~m})$ 
$\left(\sigma_{c} \cdot \max \right)$ が大きくなり，圧縮応力が圧縮縁付近に集中 乙直線分布と大きな違いを示す傾向があるが，引張応力 度分布性状は $\alpha$ および $\varepsilon_{0}$ について大きな差は認められ ない.また圧縮応力についても $\alpha$ が 1.0 以上の領域で は大きな差は認められない。 $\sigma_{c} \cdot \max$ の大きさは $\alpha$ が 0.667 以下の場合パネル中央付近の $\mathrm{a}^{\prime}-\mathrm{a}^{\prime}$ 断面で最も大 きく, $\alpha$ が 1.0 以上ではパネル長の $1 / 4$ 点 $\left(b^{\prime}-b^{\prime}\right.$ 断 面）で大きくなる. これは面外変位の $Y$ 軸方向分布差 によるもので， $\alpha$ が大きくなるにつれて面外変位の $y$ 軸 方向分布における最大值が生ずる点がパネル中央部から 載荷辺の方へ移動するのに対応している.

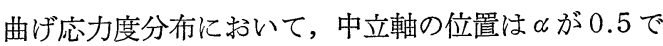
引張側に偏っていたものが，0.667 の場合にほぼ中央に 位置し， $\alpha$ が大きく なるにつれて圧縮側 へ移動する.

面内曲げ応力度分 布は応力レベルの比 較的低い部分から直 線分布の形を失い, 圧縮応力分布は圧縮 縁に偏ってくる.こ の偏り方は応力レベ ルの増加とともに著 しくなり， いほど， $R$ が小さ いほどまた が大き いほど顕著である。 以上のような傾向は 計算したすべての範

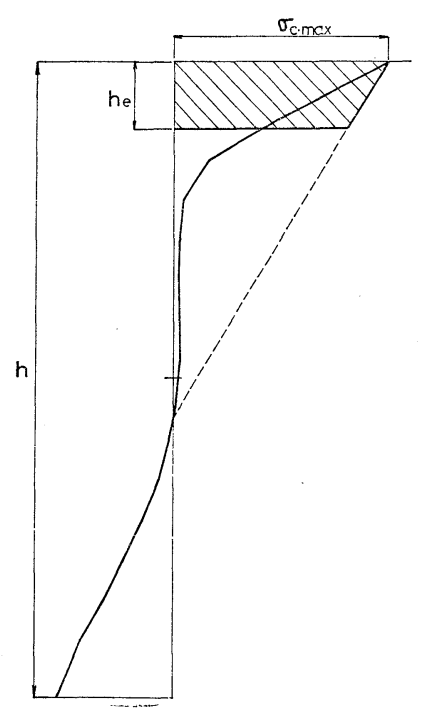

図一9 有効断面

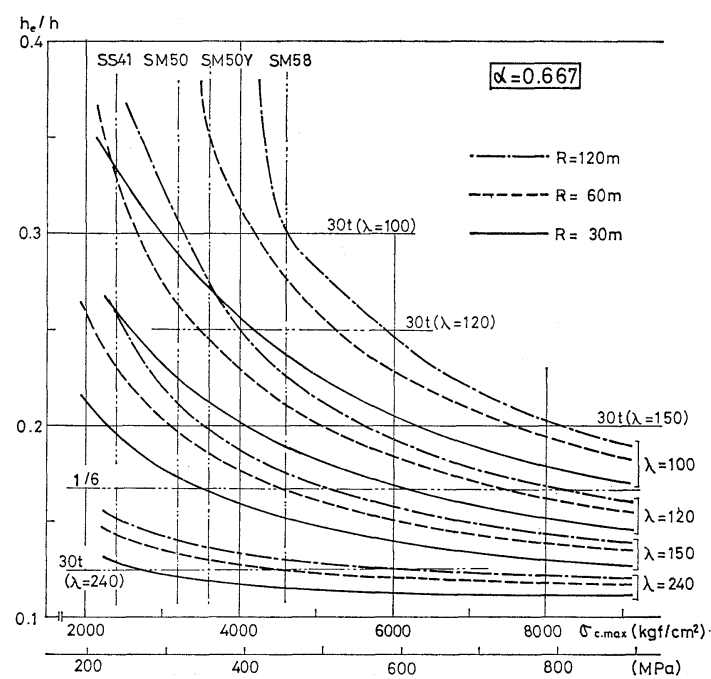

図一10 有効断面と圧縮縁応力度の関係 ( $\mathbf{a}^{\prime}-\mathbf{a}^{\prime}$ 断面), その $1(\alpha=0.667)$
囲に共通し，他のパラメーターが変化してもこの傾向は 変わらない。

圧縮応力の偏り方を評価するために，図一9のように 圧縮縁応力と中立軸を直線で結んだ分布を考え，中立軸 に関して全圧縮応力がもつモーメントと同等のモーメン 卜を与える断面 $h_{e}$ を有効断面と定義する. 図一10, 11 は $\mathrm{a}^{\prime}-\mathrm{a}^{\prime}$ 断面における有効断面と圧縮縁応力度との関係 を示す. 縦軸は有効断面をパネル高 $h$ で無次元化した $h_{e} / h$ で表示している.

図一10 は $\alpha$ が 0.667 の場合について，入および $R$ をパラメーターとして表示したものである. 同一の $R$ についてみると，入による影響が著しく $\lambda$ が大きいほ ぞ $h_{e} / h$ が小さくなる. 図の曲線のうち, $\lambda=100$ で $R$ $=60 \mathrm{~m}$ および $120 \mathrm{~m}$ の線が応力レベルの低い領域で $h_{e} / h$ が発散する傾向を示すが，これは曲げ応力の分布 形によるものである.すなわち,一般の場合,曲げ応力分 布は線形分布に対して凹形の分布をなすが，板厚が大き く半径が大きい場合，応力レベルの低い領域では線形分 布に対して凸形の分布をすることによる. 同一の入の 場合， $R$ が小さいほど $h_{e} / h$ が小さくなる. また, すべ ての $\lambda$ について $R$ が $120 \mathrm{~m}$ と $60 \mathrm{~m}$ との差が $60 \mathrm{~m}$ と $30 \mathrm{~m}$ との差より小さいことは,直線パネル $(R=\infty)$ の場合には $h_{e} / h$ の限界值が存在することを示唆してい ると思われる.これらの傾向は他の縦横比の場合にも一 般的に認められるものである。

図一11 は久が 240 の場合の のの影響を示したもの である. 図の縦軸は 図一10より桩大されているが， が小さいほど $h_{e} / h$ が小さく， $\alpha$ の影響は $R$ よりは大 きく，入よりはるかに小さい，この傾向もまた他の幅厚 比についても一般的に認められる.

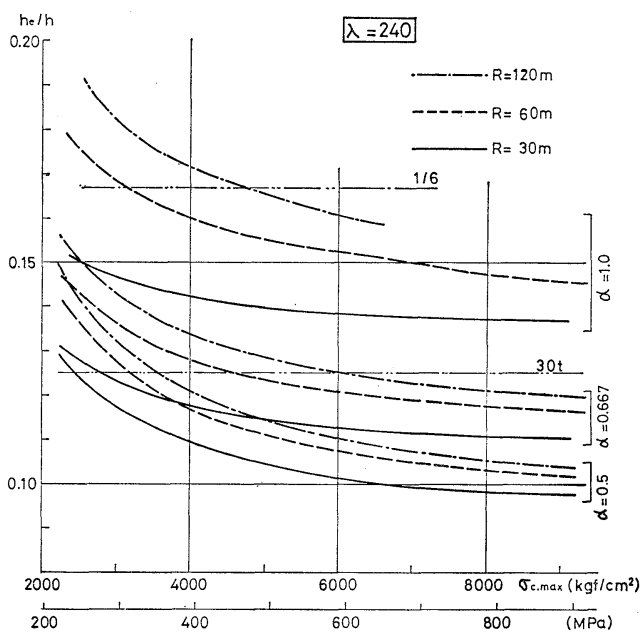

図一11 有効断面と圧縮縁応力度の関係 ( $\mathbf{a}^{\prime}-\mathbf{a}^{\prime}$ 断面), その $2(\lambda=240)$ 
直線パネルの場合, 有効断面は, $30 t$ ( $t$ はパネル厚) が提案されている.これらの線を 図一10,11 に細線で 示す. 図中に有効断面を $h / 6$ とした場合も記入されて いる. 図示された応カレベルの範囲で考察すると次のこ とがいえる.

ウェブプレートのみで考えると有効断面を $30 t$ とし た場合には， $\alpha=0.667, R=30 \mathrm{~m}$ の場合には $\lambda=100$ で $3000 \mathrm{kgf} / \mathrm{cm}^{2}(294 \mathrm{MPa}), \lambda=120$ で $2600 \mathrm{kgf} / \mathrm{cm}^{2}(255$ $\mathrm{MPa}), \lambda=150$ で $2300 \mathrm{kgf} / \mathrm{cm}^{2}(225 \mathrm{MPa}), \lambda=240$ で $2700 \mathrm{kgf} / \mathrm{cm}^{2}(265 \mathrm{MPa})$ を超える応力レベルでは危険 側となる．また有効断面を $h / 6$ とすると， $\alpha=0.667$ の 場合で有効断面の小さい $R=30 \mathrm{~m}$ について考えると, $\lambda=100$ では安全側に入るが， $\lambda=120$ で $6150 \mathrm{kgf} / \mathrm{cm}^{2}$ (603 MPa), $\lambda=150$ で $3600 \mathrm{kgf} / \mathrm{cm}^{2}(353 \mathrm{MPa})$ 以上の 応力レベルで危険側に入る. $\lambda=240$ では $\alpha$ が 1.0 以 上, $R$ が $60 \mathrm{~m}$ 以上でかつ応力レベルの低い一部を除 いてすべての領域で危険側の評価となる.

表一4 注解析結果から得られた各種鋼材の降伏点応力 度における有効断面 $h_{e} / h$ を示す.

以上のように有効断面 は幅厚比, 応力レベル, 縌横 比, 曲率半径等のすべてのパラメーターの影響を受け一 定の值を与えることは困難である．特に本論文の境界条 件で垂直補剛材間隔を小さくしてパネルの繸横比を小さ くする場合には，有効断面が減少することを考慮しなけ ればならない，また有效断面を予測する場合は上記 4 つ のパラメーターの関数となることを考慮に入れる必要が ある。

\section{（2）曲げ有限変形に伴う円周方向面内調整圧縮力}

2. (2)で述べたように，側辺に曲げ強制変位を与えた のみでは, 曲げ応力分布が純曲げモーメント状態になら ず軸力成分が残る．曲げモーメントのみが作用している 状態をつくるためには円周方向の圧縮変位を与える必要 がある。

\section{表一4 鋼材の降伏点応力における有効断面 $\left(h_{e} / h\right)$}

\begin{tabular}{|c|c|c|c|c|c|c|}
\hline & $\sigma_{y}$ & $R(\mathrm{~m})$ & $\lambda=240$ & $\lambda=150$ & $\lambda=120$ & $\lambda=100$ \\
\hline \multirow{3}{*}{ SS 41} & \multirow{3}{*}{$\begin{array}{r}2400 \mathrm{kgf} / \mathrm{cm}^{2} \\
(235.3 \mathrm{MPa})\end{array}$} & 30 & 0.124 & 0.195 & 0.257 & 0.334 \\
\hline & & 60 & 0.142 & 0.230 & 0.328 & - \\
\hline & & 120 & 0.151 & 0.256 & - & - \\
\hline \multirow{3}{*}{ SM 50} & \multirow{3}{*}{$\begin{array}{r}3200 \mathrm{kgf} / \mathrm{cm}^{2} \\
(313.6 \mathrm{MPa})\end{array}$} & 30 & 0.121 & 0.173 & 0.224 & 0.289 \\
\hline & & 60 & 0.133 & 0.196 & 0.261 & 0.306 \\
\hline & & 120 & 0.140 & 0.211 & - & - \\
\hline \multirow{3}{*}{$\begin{array}{l}\text { SM } 50 \text { Y } \\
\text { SM } 53 \\
\text { SMA } 50\end{array}$} & \multirow{3}{*}{$\begin{array}{c}3600 \mathrm{kgf} / \mathrm{cm}^{2} \\
(352.9 \mathrm{MPa})\end{array}$} & 30 & 0.119 & 0.165 & 0.212 & 0.189 \\
\hline & & 60 & 0.130 & 0.185 & 0.245 & 0.211 \\
\hline & & 120 & 0.136 & 0.198 & 0.274 & 0.226 \\
\hline SM 58 & \multirow{3}{*}{$\begin{array}{c}4600 \mathrm{kgf} / \mathrm{cm}^{2} \\
(451.0 \mathrm{MPa})\end{array}$} & 30 & 0.115 & 0.151 & 0.189 & 0.237 \\
\hline \multirow{2}{*}{ SMA 58} & & 60 & 0.124 & 0.161 & 0.211 & 0.277 \\
\hline & & 120 & 0.130 & 0.175 & 0.226 & 0.301 \\
\hline
\end{tabular}

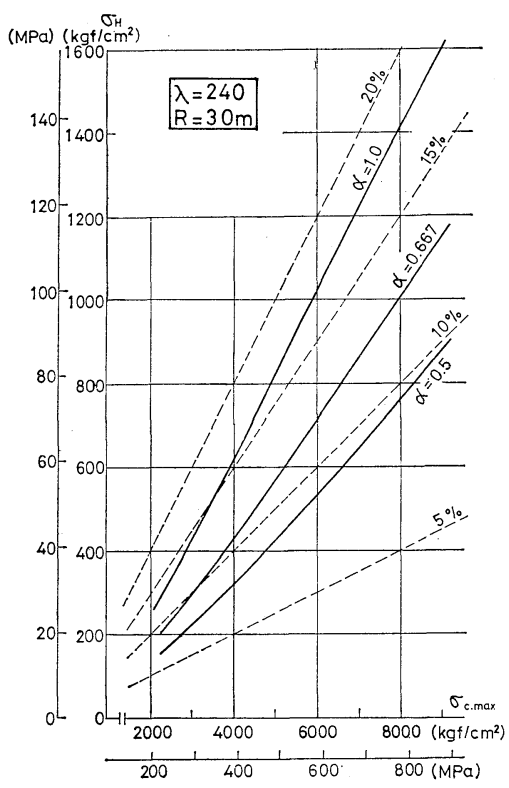

図一12 面内調整圧縮応力度と圧縮縁応力度の関係, その $1(\lambda=240, R=30 \mathrm{~m})$

載荷辺における修正変位を $\delta_{H}$ とすれば，見かけ上 $\varepsilon_{H}=\delta_{H} /(l / 2)$ の水平ひずみおよび $\sigma_{H}=E \cdot \varepsilon_{H}$ の応力が 与えられたことになる. 以下の図においては縦軸に修正 軸応力 $\sigma_{H}$ を, 横朝に圧縮縁応力度 $\sigma_{c}$. max をとり表示 する.

$\sigma_{H}$ に対する $\propto$ の影響を示すために $\lambda=240, R=30 \mathrm{~m}$ の場合の $\sigma_{H}-\sigma_{c} \cdot \max$ 曲線を例として 図一12 に示す. $\propto$ が 0.5 および 0.667 の場合での低い応力レベルの部 分を除いて $\sigma_{H}$ と $\sigma_{c \cdot \max }$ はほぼ直線的関係にあり, $\propto$ が大きいほど $\sigma_{H}$ の増加率は大きい. 図の細い破線は $\sigma_{H}$ が $\sigma_{c \cdot \max }$ の $5 \%, 10 \% ， 15 \%$ および $20 \%$ になる 線を表わしている. $\sigma_{c} \cdot \max$ が $8000 \mathrm{kgf} / \mathrm{cm}^{2}(784 \mathrm{MPa})$ の場合には $\sigma_{H}$ は $\sigma_{c \cdot \max }$ の $9.5 \%$ （ $\alpha=0.5$ の場合） から 17.3\% ( $\alpha=1.0$ の場合) に達し， $\sigma_{c} \cdot \max$ が 4000 $\mathrm{kgf} / \mathrm{cm}^{2}$ (392 MPa) の場合でもそれぞれ $8 \%, 15.5 \%$ の值になり，応カレベルが高くなるほど $\sigma_{H}$ の $\sigma_{c \cdot \max }$ に対する比は大きくなる.

$\sigma_{H}$ に対する $\lambda$ の影響の例として $, \alpha=0.667, R=30$ $\mathrm{m}$ の場合を図一13 に示す. 入が小さくなると $\sigma_{H}$ の $\sigma_{c} \cdot \max$ に対する比は減少し, $\sigma_{c \cdot \max }$ が $8000 \mathrm{kgf} / \mathrm{cm}^{2}$ (784 MPa) の場合, $\lambda=240$ で $12.5 \%$ から $\lambda=100$ の 場合の $6.6 \%$ まで, $\sigma_{c} \cdot \max$ が $4000 \mathrm{kgf} / \mathrm{cm}^{2}(392 \mathrm{MPa})$ では $10.5 \%(\lambda=240)$ から $3.4 \%(\lambda=100)$ まで減少す る。

図一14 は $\sigma_{H}$ に対する $R$ の影響を $\alpha=0.667, \lambda=$ 150 を例として示したものである. $R$ が大きいほど $\sigma_{H}$ が小さくなるがその影響は比較的小さい。

以上に述べられた $\alpha$, スおよび $R$ の影響は解析した 
すべての範囲について一般的に認められることで， $\sigma_{H}$ については $\alpha$ の影響が大きく $R$ の影響は比較的小さい といえる.

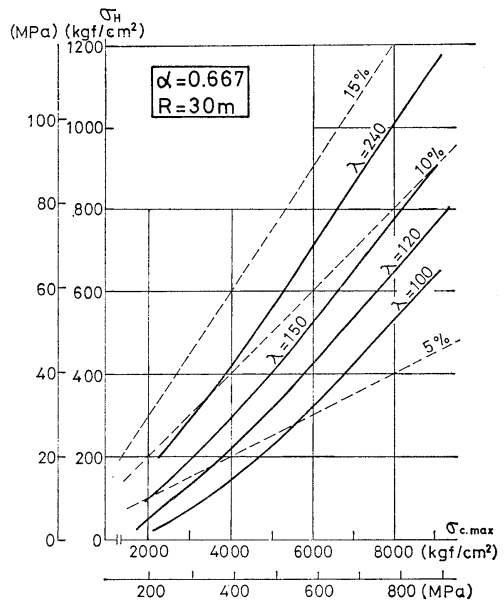

図-13 面内調整圧縮応力度と圧縮縁応力度の関係, その $2(\alpha=0.667, R=30 \mathrm{~m})$

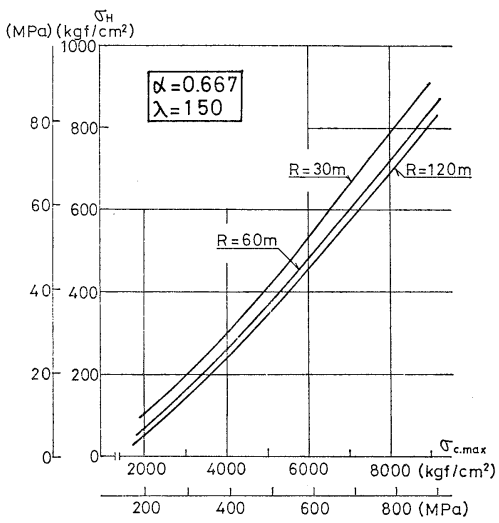

図-14 面内調整圧縮応力度と圧縮縁応力度の関係, その $3(\alpha=0.667, \lambda=150)$

\section{（3）圧縮縁における面外方向せん断応力}

曲線ウェブが曲げを受けると，圧縮縁では曲率半径の 外側に, 引張縁では内側に変形しょうとする. プレート ガーダーにおいてはこの変形がフランジによって拘束さ れ，フランジとウェブの接合部に反力を生じることにな る.この反力を面外方向せん断力とよぶと, この応力は 圧縮縁で引張縁に打汀るよりも大きく表われ，しかも圧 縮フランジの水平座屈を助長する成分となる.

図一15 17 は压縮剥の a 点および $\mathrm{c}$ 点における面外 方向せん断力と圧縮縁応力度の関係を示したものであ る. $\mathrm{b}$ 点においてはほぼ $\mathrm{a}$ 点, $\mathrm{c}$ 点の中間の值を示す. 圧縮縁の要素節点に扮ける面外方向反力 $\left(F_{Z}\right)$ を単位 長さ当たりのせん断応力 $\left(\tau_{r}\right)$ になおし, さらに単純曲 線ばりが曲げを受けたときにはりの上下縁に生ずる面外 力を式 (2) の一次理論によって求めた值 $\left(\tau_{0}\right)$ との比 $k$ $=\tau_{r} / \tau_{0}$ を縦軸にとっている.

$$
\tau_{0}=H / R=M / h / R
$$
ここで,

$M:$ はりに作用する曲げモーメント

$h:$ はりの高さ

$R:$ はりの曲率半径

$H ：$ はり圧縮縁に作用する水平方向圧縮力

図一15 は $\alpha=0.667, R=60 \mathrm{~m}$ の場合を例として $k$ に対するスの影響を示したものである. 応力レベルが 低、領域 $\left(\sigma_{c} \cdot \max =2000 \mathrm{kgf} / \mathrm{cm}^{2}(196 \mathrm{MPa})\right.$ 付近) では せん断力 $k$ は 1 3 程度でパネル全体にわたり比較的 均一に近い分布を示寸. $\lambda=240$ の場合, $k$ は応力レベ ルの増加に伴って, $\mathrm{c}$ 点のみが増加して $\mathrm{a}$ 点では減少す るので, せん断応力は $\mathrm{c}$ 点に強く分布することになる. $\lambda$ が小さいほど, a , c 2 点間における $k$ の増加の様子 に差がなくなり，せん断力はパネル全体にほぼ均一に分

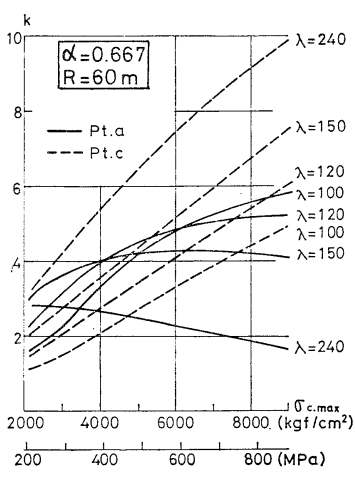

図一15 面外方向せん断力と圧縮縁 応力度の関係, その 1 $(\alpha=0.667, R=60 \mathrm{~m})$

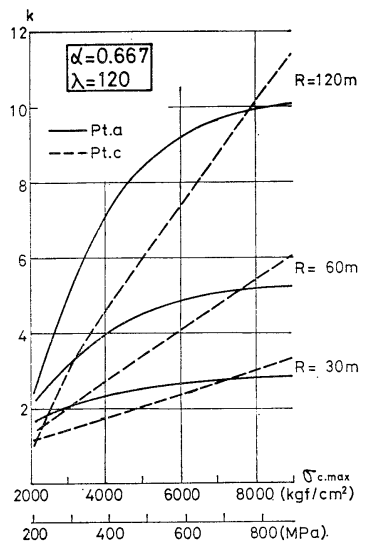

図一16 面外方向せん断力と圧縮縁 応力度の関係, その 2 $(\alpha=0.667, \lambda=120)$

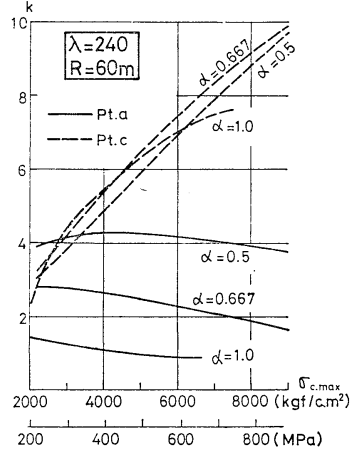

図一17 面外方向せん断力と圧縮縁 応力度の関係, その 3 $(\lambda=240, R=60 \mathrm{~m})$ 
布する. $\sigma_{c} \cdot \max =4000 \mathrm{kgf} / \mathrm{cm}^{2}(392 \mathrm{MPa})$ と $8000 \mathrm{kgf} /$ $\mathrm{cm}^{2}(784 \mathrm{MPa})$ における $k$ の值は $\lambda$ の大きい順にそれ ぞれ 5.6 ( $\mathrm{c}$ 点)，4.0，3.9，3.3 (各 $\mathrm{a}$ 点) および 9.2 , $6.7,5.4$ (各 $\mathrm{c}$ 点), 5.6 ( $\mathrm{a}$ 点) となり, $\lambda=240$ の場 合には $\lambda=100$ の場合の $1.7 \sim 1.64$ 倍になる.

図一16 は $k$ に対する $R$ の影響の例を示したもので ある. $R$ が大きいほど $k$ の值は大きく, $\sigma_{c \cdot \max }=8000$ $\mathrm{kgf} / \mathrm{cm}^{2}(784 \mathrm{MPa})$ で $R=120 \mathrm{~m}$ の場合約 $10,60 \mathrm{~m}$ の 場合約 $5,30 \mathrm{~m}$ の場合約 3 程度の值となり $R=120 \mathrm{~m}$ の場合には $30 \mathrm{~m}$ の場合の 3 倍以上になる. しかし一次 理論による值 $\tau_{0}$ は半径に逆比例して小さくなるため, せん断力の絶対值は $R$ によって大きな差は生じない.

図一17に $\lambda=240, R=60 \mathrm{~m}$ の場合を示す. c 点の $k$

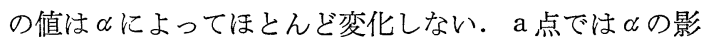
響を受けるが, その值は $\mathrm{c}$ 点に比較して小さく設計上の 問題は少ない。

以上に述べられた各パラメーターの影響は, 例として 図示された場合に限らず，解析範囲全体について一般的 に認められる傾向である. 面外方向せん断力の平均值は $R$ によって定まり，パネルに打ける分布の様子は $\lambda に$ よって定められる傾向があり，のの影響 は少ない，本 論文による解析結果はいずれも一次理論による值を上回 り, 一次理論によって計算した場合, 特に曲率半径の大 きい場合にはせん断力を $1 / 10$ 位に過少評価する危険が ある. 一般的に 1.0 以上の縦横比を用いる場合にはフラ ンジの水平座屈に対して, せん断力がパネル中央あるい はパネル全体に均一に分布する場合, すなわち幅厚比が 小さい場合には十分に検討することが必要である.

\section{（4）垂直方向变位}

円筒パネルは曲げを受けて垂直方向に変位するが，圧 縮縁の変位量が引張縁のそれより大きいため, パネルは 見かけ上，上下フランジ間隔が縮まったような状態とな る.この変形はフランジも含めた断面の曲げ抵抗力を減 少させるとともに，フランジのいわゆる垂直座屈にも影 響を与える. 見かけ上の垂直ひずみを $\varepsilon_{u}=\left(u_{c}-u_{t}\right) / h$ で定義する.ここに，

\section{$u_{c}$ : パネル中央線上の圧縮縁の垂直方向変位} $u_{t}:$ パネル中央線上の引張縁の垂直方向変位 $h:$ パネルの高さ

図一18 はひずみ $\varepsilon_{u}$ と圧縮縁応力度 $\sigma_{c} \cdot \max$ の関係を 表わしたものである. $\lambda=150,120$ の場合については $R$ $=30 \mathrm{~m}$ のみを表示するが， $R$ に関して $\lambda=240$ と 100 の中間の性質を示す． $\varepsilon_{u}$ はほぼ $\lambda$ にのみ依存し $\lambda$ が 小さいほど $\varepsilon_{u}$ が小さくなるが，面外たわみの影響を受 けて単純な関係にはならない。 $\lambda$ が 120 より小さい場 合には $R$ が小さいほど $\varepsilon_{u}$ が大きく, が 150 より大

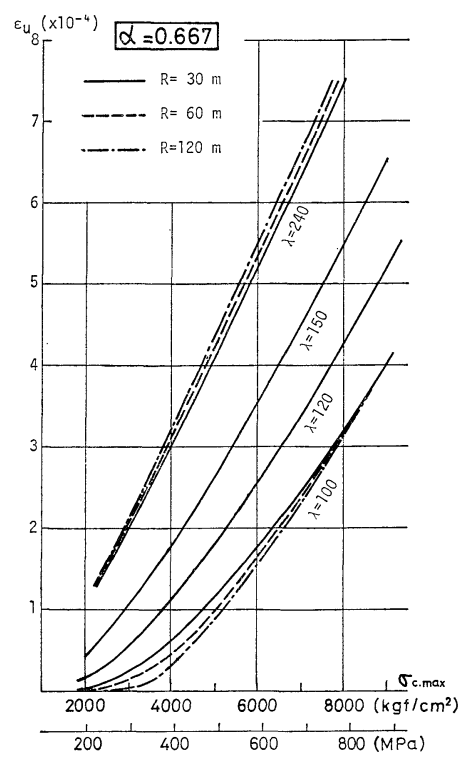

図一18 面内垂直ひずみと圧縮縁応力度の関係 $(\alpha=0.667)$ きい場合には $R$ が大きいほど $\varepsilon_{\mathfrak{u}}$ が大きくなるがその 影響は小さい，また図沙省略するが $\alpha$ が小さいほど $\varepsilon_{u}$ が小さくなる傾向があるが， 几の值が大きな影響を与え ることはない.しかしフランジの垂直座屈を論じる場合 には, さらにウェブプレートのこういった垂直方向変位 とともに垂直方向ば社定数の検討が必要となろう.

\section{（5）ウェブと圧縮フランジ接合部に生ずる 拘束モーメント}

直線プレートガーダーに繰返しの曲げモーメントを作 用させた場合, 圧縮フランジとウェブの接合部の隅肉溶 接部に亀裂が発生することが報告されている ${ }^{11)}$ 。これは 接合部に発生する拘束モーメント $\left(m_{r}\right)$ が繰り返し作用 することによる疲労に起因するものと思われるが, 曲線 プレートガーダーの場合には, より大きなモーメントが 生ずる.このモーメントの大きさは動的には振動倍率や 構造の減衰率によるが, 静的にはフランジのウェブに対 する拘束の度合によって，大きさが左右されるものであ り,フランジがウェブの面外変位を完全に拘束するとき に最大の值になることは明らかである．この状態は本論 文で解析の対象となっているパネルの非載荷辺の単純支 持を回転に関して固定とすることで得られる．以下の図 において圧縮縁方向の単位長さ当たりの拘束モーメント を縦軸にとっている. 図では $\mathrm{a}$ 点, $\mathrm{c}$ 点のみを示すが, $\mathrm{b}$ 点では両者のほぼ中間位の性質を示す.

図一19 は $\alpha=0.667, R=60 \mathrm{~m}$ の場合の $m_{r}$ と $\sigma_{c \cdot \max }$ の関係を示す. $m_{r}$ の分布は $\lambda=240$ の場合, $\mathrm{c}$ 点に大 きく現われるがその值は応力レベルが高くなってもあま り増加しない．またa 点の $m_{r}$ は応力レベルが高くなる 

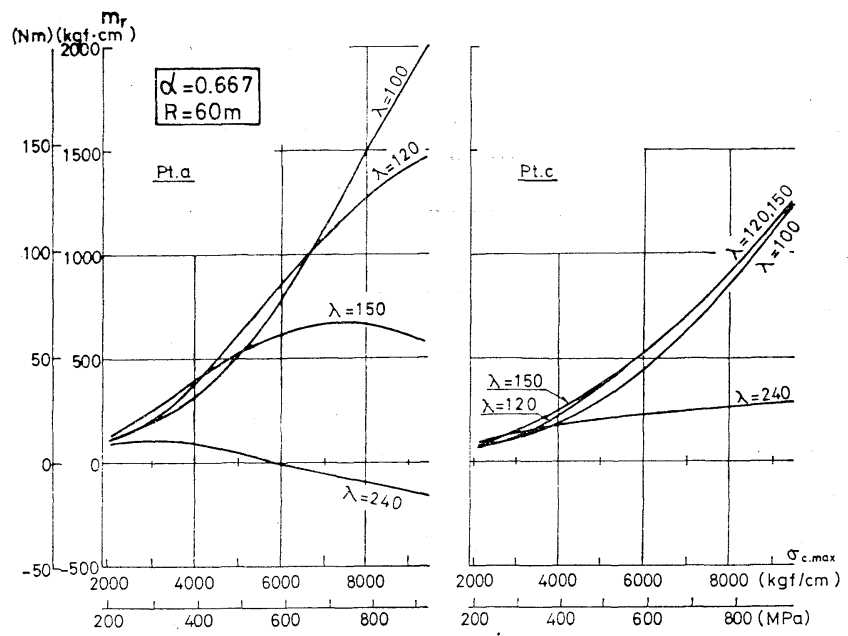

図一19 圧縮フランジとウェブ接合部の拘束モーメントと圧縮縁 応力度の関係, その $1(\alpha=0.667, \mathrm{R}=60 \mathrm{~m})$

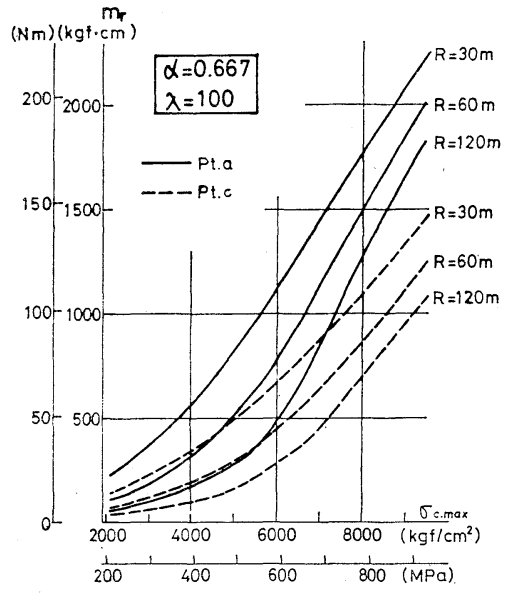

図一20 圧縮フランジとウェブ接合部の拘束 モーメントと圧縮縁応力度の関係, その $2(\alpha=0.667, \lambda=100)$
につれて減少し， $6000 \mathrm{kgf} / \mathrm{cm}^{2}(588 \mathrm{MPa})$ 以上では負 の值をとる. $\lambda$ が 150 以上の場合, $\mathrm{c}$ 点の $m_{r}$ は応力 レベルが高くなるにつれて大きくなり $\lambda$ の值によらず ほぼ同一の值をとる．ａ 点の $m_{r}$ は応力レベルの低い領

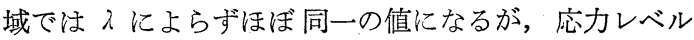

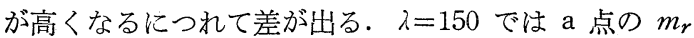
は $7500 \mathrm{kgf} / \mathrm{cm}^{2}(735 \mathrm{MPa})$ で最大に達したのち減少す るので $6800 \mathrm{kgf} / \mathrm{cm}^{2}(667 \mathrm{MPa})$ 以上の応カレベルでは $\mathrm{c}$ 点の方が大きくなる. $\lambda=120$ の場合には $\mathrm{a}$ 点, $\mathrm{c}$ 点と もに同柡の増加を示すのでパネル全体にほぼ均一に分布 する. $\lambda=100$ の場合には a 点の $m_{r}$ が大きく応力レベ ルが高くなるにつれて $\mathrm{a}, \mathrm{c}$ 間の值の差は大きくなる.

パネルに分布する $m_{r}$ の最大值は応力レベルが 4000 $\mathrm{kgf} / \mathrm{cm}^{2}(392 \mathrm{MPa})$ のとき $180 \mathrm{kgf} \cdot \mathrm{cm}(17.6 \mathrm{Nm})[\lambda=$ 240]抢よび 300 400 kgf •cm (29.4 39.2 Nm) [ $\lambda=150$, $120,100]$ と大差ない值を示すが， $8000 \mathrm{kgf} / \mathrm{cm}^{2}(784$ $\mathrm{MPa})$ のレベルではそれぞれ $260 \mathrm{kgf} \cdot \mathrm{cm}(25.5 \mathrm{Nm})[\lambda$ $=240], 670 \mathrm{kgf} \cdot \mathrm{cm}(65.7 \mathrm{Nm})[\lambda=150], 1270 \mathrm{kgf} \cdot \mathrm{cm}$ $(125 \mathrm{Nm})[\lambda=120]$ および $1500 \mathrm{kgf} \cdot \mathrm{cm}(147 \mathrm{Nm})[\lambda=$ 100]となり, $m_{r}$ は $\lambda=100$ の場合に $\lambda=240$ の場合の 6 倍近い值になる.

図一20 は $m_{r}$ に関する $R$ の影響を $\alpha=0.667, \lambda=100$ を例として示したものである. $R$ が小さいほど $m_{r}$ は大 きくなり応力レベルが $5000 \mathrm{kgf} / \mathrm{cm}^{2}(490 \mathrm{MPa})$. 付近で は $R=30 \mathrm{~m}$ の場合に $R=120 \mathrm{~m}$ の場合の 3 倍になる.

\section{4. 結 論}

本論文ではプレートガーダーのウェブプレートのみを 取り出して，曲げ作用を受ける場合を対象として論じた が，実際の設計にあたってはフランジとの連成効果やウ
ェブの耐荷力を向上させるための垂直および水平補剛材 の配置およびその必要剛度などの検討が必要である. 同 様にウェブのせん断力に対する挙動や補剛効果も明らか にされなければならない，また桁の最終耐力を論ずる場 合には材料の弾塑性をも考慮した解析が要求されよう。

しかし本論文で行ったように, ウェブプレートのみを 取り出して，これを円筒パネルとみなして四角形円筒要 素を用いた有限要素法による有限変形解析を行った結 果, 仮定された境界条件とパラメーター範囲では, 以下 の結論を得た。

（1）ウェブを部分構造として取り出して曲げに対す る挙動を解析する場合, 全体構造との適合性を満足させ るためには曲げ強制変形を与える必要がある.

（2）（1）の場合, パネルの面内曲价応力分布形は純 曲げモーメントの状態とはならず引張応力が軸力成分と して残る. したがって, この軸力成分を打ち消すために は面内一様圧縮変位を与去なければならない。

（3）面内曲げ圧縮応力はウェブの圧縮縁近傍に集中 的に生じ, この偏り方は応カレベルが高いほど著しい. この傾向は縦横比が小さいほど, 曲率半径が小さいほど また幅厚比が大きいほど顕著である.

（4）（3）の結果として曲げ圧縮応力に関する有効断 面 $\left(h_{e} / h\right)$ の大きさは, 幅厚比の影響を最も強く受け幅 厚比が大きいほど小さくなる.また縦横比が小さいほど あるいは曲率半径が小さいほど小さくなるが後者の影響 注前者の影響より小さい. 有効断面を板厚の 30 倍と評 価することは, 線形座屈解析で縁応力を降伏応力と一致 させたときに得られる幅厚比を用いる場合には危険側と なる場合があり，有効断面をウェブ高の $1 / 6$ と評価する 方が解析結果を説明しやすい。

（5）面内曲げ応力分布を修正するための軸方向圧縮 
応力は，縦横比と幅厚比の影響が大きく，いずれもその 值が大きいほど修正応力が大きくなり，圧縮縁応力度の 17\% を超える場合もある. この修正応力は曲率半径に よっては大きな影響を受けない.

（6）圧縮縁に生ずる水平面外方向せん断力分布は幅 厚比の影響を強く受け，幅厚比が小さいほどパネル中央 部分に強く分布する. このせん断力は設計上では縦横比 や曲率半径の影響は少ないが，一次理論で評価すること は 1/10 位の過少評価となることがあり危険である.

（7）パネル中央部に打ける見かけ上の垂直ひずみ は，ほとんぞ幅厚比のみによって決定され，縦横比や曲 率半径には鈍感である.このひずみは幅厚比が大きいほ ぞ大きくなる.

（8）圧縮フランジとウェブの接合部に生ずる拘束モ ーメントは幅厚比によって, また曲率半径によって数倍 になる場合がある．両者ともその值が小さいほど拘束モ ーメントは大きくなる.

\section{5. あとがき}

本論文は元東北大学大学院学生 岡部安水君により始 められたものであり，同君の努力に感謝したい．また本 研究の一部は文部省科学研究費の補助を受けた. 数值計 算には東北大学大型計算機 センターの ACOS NEAC700 , 同じくACOS·NEAC-900 ならびに東北学院大学 計算センターの FACŌM・M 140-F を用いた。

\section{参 考 文 献}

1) Basler, K. and B. Thürlimann : Strength of plate girders in bending, Proc. of ASCE, ST 6, pp. 153 181, Aug., 1961.

2）森沢・三上 : 円周方向引張力を受ける曲りばり円筒フラ
ンジの非線形挙動, 土木学会第 34 回年次学術講演会講演 概要集, I -108, pp. 214 215, 1979, ほか.

3）大塚・吉村・片桐 : 有限帯板法による曲線 I 桁の弾塑性 座屈強度解析, 土木学会第 34 回年次学術講演会講演概要 集, I -125, pp. 248 249, 1979.

4) Brebbia, C. and J. Connor : Geometrically nonlinear finite-element analysis, Proc. of ASCE, 95, EM 2, pp. 463 483, April, 1967.

5) Gallagher, R.H. : The Development and Evaluation of Matrix Methods for Thin shell Structural Analysis, Ph.D. thesis, State Univ. of New York, Buffalo, New York, 1966.

6) Bogner, F.K. et al. : A cylindrical shell discrete element; AIAA Jour., Vol. 5, No. 4, pp. $745 \sim 750$, 1967.

7) Cantin, G. and R.W. Clough : A curved cylindricalshell, finite element, AIAA Jour., Vol. 6, No. 6, pp. 1057 1062, 1968.

8) Sabir, A.B. and A.C. Lock : A curved cylindrical shell, finite element, Int. Jour. Mech. Sci., Vol. 14, pp. 125 135, 1972.

9) Ashwell, D.G. and A.B. Sabir : A new cylindrical shell finite element based on simple independent strain functions, Int. J. Mech. Sci., Vol. 14, pp. 171 $\sim 183,1972$.

10) Megård, G. : Planar and curved shell elements, Finite Element Methods in Stress Analysis, ed. Holand, I. \& K. Bell, pp. 287 312, TAPIR, 1969.

11）大倉・前田：薄肉プレート・ガーダのウェブ周辺溶接部 の疲労に関する研究, 土木学会第 34 回年次学術講演会講 演概要集, I - 49, pp. 97〜98, 1979, ほか一連の研究.

12) Ashwell, D.G. and R.H. Gallagher (editors) : Finite Elements for Thin Shells \& Curved Members, John Wiley \& Sons, 1976.

13）川股重也：コンピュータによる構造工学講座 II-6-A シ エル構造解析, 培風館, 1974 .

14）樋沒・倉西 : 曲線橋のウェブ応力について, 土木学会第 33 回年次学術講演会講演概要集, I - 51, pp. 99 100, 1978.

15）樋渡・倉西 : 曲げを受ける円筒シェルの応力, 土木学会第 34 回年次学術講演会講演概要集, I - 106, pp. 210 211, 1979 .

(1980.7.16 - 受付) 